\title{
Academic Homecoming. Stories from the Field
}

\author{
Frans Kamsteeg
}

\begin{abstract}
Academics world-wide experience the daily consequences of the sell-out that neoliberal universities euphemistically frame as a combination of effectiveness, efficiency and excellence. In this contribution I use fiction, and in particular John Williams' recently rediscovered novel Stoner, to illustrate how painfully tangible these effects become in daily academic practice. The Stoner book shows the imbroglio of an aspiring American literature professor, whose career is presented as a symbol of the increasing academic depreciation of knowledge and Bildung. I argue that the literary quality of Stoner and other 'academic novels' can better than any sociological study convey the detrimental consequences of the unhappy marriage of ignorance, measurability and accountability that reigns today's universities. Sparked by an auto-ethnographic account of academic quality measurement I plea for maintaining what is still left of 'academic passion', hoping to prevent academia and its inhabitants from suffering the same tragic fate as many a protagonist in academic novels.
\end{abstract}

\section{Keywords}

public academic life - literature - belonging - quality - accountability

\section{$1 \quad$ Introduction: on Academic Sell-out}

Somewhere in the past, writes Robert Birnbaum, 'being a professional was ennobling [...presuming] a calling - a vocation - and a dedication to service' (2000, p. 225). Perhaps it is this Weberian and Humboldtian vocational ideal that makes university inhabitants generally feel 'at home', although feelings of unease and even alienation have entered the university over the last two decades, provoking what Nussbaum calls 'the silent crisis' (2010). Already in 1997 Bill Readings wrote his University in Ruins in which he ascertained that the university was rapidly handing over its autonomy to the market and its bureaucratic aligning, but recent struggles in African, North-American, and 
European universities urgently put the global forces of marketisation, neoliberalisation, and the resulting alienation in the university back on the agenda again. In South Africa this alienation has taken a particularly articulated form. As Tabensky and Matthews (2015) explain, the South African higher education sector under apartheid ceased to be an inclusive 'home' and was transformed into an ambiguous place where students and staff were forcefully allocated and separated, thus gaining all the characteristics of a non-home. In 2015, ten years after a radical higher-education restructuring, the Rhodes-must-fall student protests in South African targeted not only the heritage of apartheid and colonisation of higher education institutions as such, but also questioned their 'colonised' curricula and institutional practices and their roots in European and global Northern canons. South African higher education then was taking stock of where it stood in terms of post-apartheid transformation. In all of the Afrikaner- and English-speaking universities students (sometimes supported by staff) were demanding to be finally freed from the symbols and practices of the not-so-recent past. The Rhodes-must-fall movement, that started at one of South Africa's internationally most prestigious universities, the University of Cape Town, was the starting-point of a stream of critical voices urging lower fees and a change in the academic set-up and governance structure of practically all institutions of higher education in the country (Booysen, 2016; Jansen, 2017; Ray, 2016). In most cases this meant that black and white students and staff claimed co-ownership of the institutions in which they felt unwelcome strangers because of the dominant institutional culture of whiteness inhibiting them from identifying with their places of study (Higgins, 2013; Jansen, 2009). The particular kinds and forms of knowledge that is privileged by these dominant cultures further deprived many students and staff of the possibility of feeling at home, a process that was only further exacerbated by the expanding neoliberal globalisation and governance at South Africa's universities after its democratic turn in 1994.

In the age of the 'consumer university' (Bauman \& Donskis, 2013; see also Boutellier, 2015) this feeling of not-belonging and non-ownership, so evidently present in South Africa, is, however, widely shared in academia worldwide. In South Africa it is the apartheid-legacy and colonial institutional cultural trap that ignited the universities, while the same experience of expropriation and decolonialisation also became prominent in the 2015 protests in the Netherlands and other Western countries, including the USA. Staff and students rose against what is called 'the spirit of effectiveness, efficiency and accountability' governing present-day universities. Particularly academics from the humanities and social sciences severely criticise this neoliberal trend or 'fad', as Birnbaum already labelled it in 2000. Universities have turned from homes of 'gay science' 
into orphanages of knowledge, transforming all their inhabitants into market competitors in a rat race to produce knowledge (citations) and push knowledge consumers (students) through the pipeline of the knowledge economy jungle (Birnbaum, 1988, 2000; Gibbons 1994; Nussbaum, 2010; Noordegraaf \& Schinkel, 2011). A typology of present-day universities by Paradeise \& Thoenig (2013), for instance, reserves the label 'wannabes' for those universities ruled over by this kind of opportunistic utilitarianism regime, but it could just as easily be argued that this 'rationale' has affected and infected the full spectrum of institutions of higher learning, including those 'venerables' that top the various international rankings, which supposedly measure their quality.

Without idealising any form of ivory tower academia, the passionate and joyful science Nietzsche describes - be it with some irony - in The Gay Science is governed by the 'will henceforth to question further, more deeply, severely, harshly, evilly, and quietly than one had previously questioned (2008, p. 7)'. Already in 1882 Nietzsche saw that this academic practice was ceasing 'to [...] a calculus of utility' (ibid., p. 201). He maintains that this 'utility' science can never represent the spirit of true science that 'must have originated in spite of the fact that the disutility and dangerousness of "the will to truth" or "truth at any price" is proved to it constantly' (ibid.). It is about time to acknowledge the importance for academics to reconfirm 'the importance of being earnest', as Nussbaum writes in her Political Emotions (2013), where she - building on Rawls - accentuates the key role to be played by (political) emotions, and particularly love and passion/compassion as the lubricants of society. In her view these fundamental emotions, first promoted in the family, are further taught at school, to - finally - fully develop in academia. Teaching critical freedom and the right to dissent create the circumstances for love and hence contribute to the promotion of the common good and the building of a sustainable and just society. To Nussbaum this just society rests upon the premise that it invites rather than coerces, which means that a critical spirit is leading, in which everything is subject to enquiry. It is this inquisitive and questioning mind that is to be taught at university - paired to an unconditional support of the inviolable principles of equality and justice, together fuelling love as the driving societal force. Hence public rituals, ceremonies, and stories, as well as systems of education, must be constructed on these fundamental values. Nussbaum invokes John Stuart Mill's inaugural Rector's Address at the University of St. Andrews to discuss the universities' contribution to this common good - in contrast to

1 Paradeise \& Thoenig (2013) for instance distinguish between 'top of the pile', 'wannabe, 'venerable', and 'missionary' institutions, with distinctive roles for management in each of them, as well as different views on the relation between research and education. 
the pursuit of interest, valorisation, efficiency, output-effectiveness, and the corresponding accountability and audit frameworks (Nussbaum, 2013, p. 81; $82 \mathrm{ff}$ ). Yet, preaching these values and principles today requires a high degree of civil courage, moral imagination, engaged scholarship, and empathy (cf. Ignatieff, 2013; De Waal, 2008). Public scholar and veteran Noam Chomsky is perhaps the most vocal defender of this plea in his The Intellectuals and the State (2014), already put forward in his early warning The Death of American Universities (1977). In both texts Chomsky builds on Max Weber's seminal Science as a Vocation (1946 [1919]) that promotes the love of teaching, that is, teaching to educate rather than teaching to test (cf. Biesta, 2016), to which I will come back in my discussion of academic citizenship at the end of this chapter. The plea that I will make there is built upon an exploration of how academic freedom and love of science is shaped and defended in world literature.

Perhaps the most compelling way of deepening the propositions of my introduction - and maybe even this volume as a whole - is by turning to literature, a point that is also made in the last section of Donskis' previous chapter. The most telling recent story about academia in this respect is John Williams' epic novel Stoner (2006 [1965]), a presently immensely popular book in the Western world. It is about a university professor (Stoner) whose love for English literature (which I take as a symbol for academic culture in general) remains unbroken despite the surrounding culture of an American university largely inhabited by mediocre people whose prime objective seems to be protecting the institutional order rather than academic standards. Stoner's story is that of an academic amateur - in the literal, positive sense of the word - who little by little becomes crushed by the small-minded micro politics that even compromises his most enlightened intellectual allies.

\section{A Tragic Story}

John Williams opens his book by telling the story of a university student from an impoverished farm who is struck to silence by a Shakespearean sonnet in his second year at an American Midwestern college, and subsequently decides to become a teacher in Medieval English literature himself, because his professor tells him so: 'you are in love, it's as simple as that' (p. 20). Stoner and his study friends discuss what they call the true nature of the university, which they decide to be 'The True, the Good, the Beautiful, just laying around the corner' (p. 29). For Stoner this is, however, not the beginning of a bright future. 
Being a 'dreamer' in the words of one of his friends, it takes him a while to master the required teaching skills, but as soon as he starts believing that his own love of literature will bear fruit among his students, he gets entangled in the messiness of classroom demeanour, student apathy, and bureaucracy. After a brief but promising career as an assistant professor, he becomes a classic and tragic academic figure, ${ }^{2}$ and gradually sinks into oblivion.

Williams' novel on the gloomy life of this academic loner and outsider recently became a bestseller, more than fifty years after its first edition in 1963. We can only guess why the book became so popular, but it is tempting to suggest it is because the text makes a passionate plea for the (academic) craftsmanship that Sennett (2008) maintains requires a re-appreciation of the skills and energy required for really good work, that is so in danger of being discredited in today's world. Although Stoner is most often lauded for its empathetic story of a man being misrecognised and belittled in his work (and by his wife for that matter), I believe it can also serve to draw some important lessons about 'the true nature of the University' (p. 29) and what makes for its quality, that almost metaphysical concept that is so hard to define, but that nevertheless 'for all practical purposes [...] really does exists' as Robert Pirsig argues in his classic Zen and the Art of Motorcycle Maintenance (1974, p. 187). This argument about academic quality is best illustrated when as a fresh university professor Stoner fails a graduate course student who is supervised by a colleague of his, because of his last-minute handing in of an incomplete, superficial, and partly plagiarised assignment. He qualifies this as proof of the student's 'laziness and dishonesty and ignorance', and advises him to consider leaving the university for the simple reason of not being entitled to have 'a place in a graduate program' (p. 147). Here Stoner uses the quality argument suggested by Pirsig (1974, p. 251) when he explains to the student that he simply did not produce the correct qualitative response to what an academic environment expected of him.

One could argue that what happened here was just an incident - after all for students in general internalising the academic habitus is time and energy consuming - yet the subsequent part of the story rather painfully shows the opposite: this student consciously refuses not only to revise his work but rather defiantly accuses Stoner of assessing him on the basis of unjustified criteria. When Stoner is later on required to be a member of the committee that has to examine the same student orally, it soon dawns on him that what just seemed a mere incident is turning into something far bigger than this. During the examination by Stoner it is the student's supervisor who changes the course of things. Instead of valuing Stoner for defending academic standards and

2 This is not how John Williams would see it (see page xii). 
quality, his colleague becomes his opponent and tries to force him to accept the student's mediocrity by shrewdly guiding the student in his answers to Stoner's questions, while the two slightly intimidated other members - one being his old friend and the chairman of the committee - stay aloof, a choice that could well be considered to represent an attitude increasingly current in academia. Stoner, however, is not willing to budge an inch and relentlessly keeps questioning the student so that his disqualification becomes evident. The final verdict is postponed, but the student's supervisor assures his pupil that he has nothing to worry about.

After failing this Master's student in his course, and subsequently in his final exams, for an apparent lack of quality, Stoner refuses to think of accepting the position of department head, which is taken by the same colleague whose student he has failed. This is the part where from an academic perspective the story really becomes depressing. For it is only after the confrontational meeting that the chairman of the session tells his old friend Stoner that his opponent - the student's supervisor - will be the new head of the department. This is the moment they both realise that a point of no return has been passed. His friend tries to console Stoner with the remark that they (the university?) cannot keep 'this kind of student' out, to which Stoner objects that at least they can try, because 'it would be a disaster to let him [the student] loose in a classroom' (p. 167). The next day Stoner is threatened by his opponent with the charge of prejudice against the student during the exam, and even in the regular classes preceding the exam. In the end there are no charges, but for the next semester the new department's head removes him from all of his previous teaching responsibilities. Stoner then realises 'that is was possible that he might leave the University, that he might teach elsewhere' (p. 173), but his wife who is the last judge immediately rejects the idea: 'You should have thought of this before, of what it might lead to. A cripple. [...] Honestly, things are so important to you. What difference could it make?' (p. 174). The battle appears to have been totally lost when in the next semester the student triumphantly returns and has himself passed by a new examination committee installed by Stoner's adversary. For a while Stoner is the laughingstock of the campus, and subsequently he becomes a legend and campus character (p. 229). The shrewd machinations of his colleague using his power of chairman then results in Stoner keeping more and more to himself and slowly but surely marginalising himself from the academic community. A scandalous love affair with a student movingly described in really high-quality language - decides his fate. He is given more and more classes to teach, in which he starts experimenting with unconventional teaching methods to challenge his students. The latter start to complain even more about him, as in class he often became so immersed in 
this subject that he seemed unaware of anything or anyone around him'. More isolated than ever, his life toddles on while teaching (for more than forty years) until he finally dies of cancer alone in his house with a pile of books next to him, one of which slips through his fingers in his last minutes on earth.

It is certainly remarkable that this moving story of a crushed academic in the depressing environment of a 'quiet' American university has become something of a slow-burn sensation. Nearly two decades after its author's death in 1994, Stoner hit Europe's bestseller lists, causing a stir in Britain, America, and the Netherlands. The unexpected and widespread reappraisal has earned the epithet 'the Stoner phenomenon', despite the fact that the novel was almost forgotten soon after its publication. Perhaps it was the wrong time for publishing a novel about this ordinary man, in a far from exciting environment, the university. Yet I believe the novel has a broader appeal. The idea on which Stoner is built, namely that reading literature - in this case a poem - can become a life-turning event that, moreover, stands as a symbol for the beauty and emotion that the academic endeavour can - or should - awaken today. I would like to believe that the fact that apparently there is a broad audience for this 'small' book means that there is still room for quality, beauty, and, by implication, for academia.

\section{More Lessons from Academic Novels}

Three other novels on academic life provide us with a somewhat different picture, yet they similarly present illuminating insights into current tendencies in our universities. John Kenneth Galbraith's A Tenured Professor (1990) chronicles Harvard professor Montgomery Marvin's rise to fame as a professor of economics who, as an academic teacher, keeps a low profile but who nevertheless is given tenure quite early in his career. While concerning himself with some rather unspectacular research projects, Marvin's extracurricular activities focus on becoming rich in a very short time. For that purpose, Marvin has developed a new formula - a stock forecasting model by means of which he and his wife can cash in on people's euphoria, greed, and, as they call it, dementia. Eventually, while everyone loses money in the stock market crash of October 1987, the Marvin couple makes a fortune. They decide to spend their money wisely, according to their liberal agenda. Intent on strictly observing the code of business ethics, they start to make use of the 'positive power of wealth' and embark on a life of philanthropy. They fund a number of chairs in peace studies to be established at, of all places, military academies. They also secure legislation by which companies are required to label their products according to the percentage of female executives employed by them. After they have launched several of their projects, their operations are increasingly 
considered un-American and officially put under surveillance. But no matter what happens, Marvin knows that he will be able to nourish his family, since he has been given tenure to promote a liberal agenda. As his old protector somewhat cynically reminds him: 'anyway you still have tenure. I hope you remember that I told you to get that first' (Galbraith, 1990, p. 197).

John Hiden's Town and Gown (2012) relates how probationary U.K. lecturer Eric Farnham tries to secure his future at a time of imminent university spending cuts. He does so by grasping the chance to win extra funding for his institution through cultivating a hard-nosed local businessman and his daughter. In doing so he comes into close contact with this man's ambitious, self-taught employee, Albert, a pairing that draws Eric into a punishing series of escapades and gives him a crash course in the shadier side of the city's entrepreneurial sector. This Albert, by contrast, takes to Eric's world like a duck to water. Just as Eric decides to retrace his steps in the face of the amorality implied by his town and gown business, Albert shows him that in fact the whole of academia is involved, and that he is the exception that proves the rule. The chilling story of a lecturer drawn into amorality/complicity by merging town and gown (symbols for academia and world, good and bad, heaven and earth, etc.) provides a grim picture of present-day academia, in a way that no university annual report will ever state, but that in its detailed minutiae of the main character's slow corruption of character is nevertheless hugely telling.

Robert Pirsig's classic Zen and the Art of Motorcycle Maintenance, by many considered both a cult book and a masterpiece, is about another academic hero and his quest for quality, a quest that even drives the protagonist of the story crazy. The book is about this nearly impossible to directly measure thing we call quality, which cannot be broken down into subjects and predicates. This is not because there is anything special about quality but rather because it is so simple, immediate, and direct (p. 25). Pirsig's book is written in the societally unsettling sixties and seventies, just like Stoner, and unlike the latter, was a hit in a time when students and other intellectuals raised their voices in an emotional and imaginative protest against the rationalist, differentiating, individualising, and domesticising consequences of modernity (see Margetts \& Hood, 2010). It is quality as threatened by modernity that Pirsig tried to grasp and defend. Somewhere in the middle of the book (in chapter 20) his meticulous exploration of the quality concept comes down to the simple statement that 'quality is the response of an organism to its environment', which he then explains as the immediateness by which humans recognise quality in certain environments. Quality could also be described as the continuing stimulus that our environment puts upon us to create the world in which we live. Translated to the world of academia, it would mean that the university 
environment by implication/definition has, or should have, Pirsig's quality to create and foster the natural home for driving the intellectual passion for (new) knowledge and ideas. Quality à la Pirsig is academia's trademark, with universities as keepers of that quality where its practitioners are to feel at home, like fish in the water.

Galbraith's and Hiden's heroes, as well as Williams' figure of Stoner, put a number of important issues on the table. So, what is this academic passion Stoner stands for? How does this book display the qualities Martha Nussbaum's Not for Profit (2010) attributes to the humanities as core disciplines of the university project? Her main point stresses the idea that education is not for profit, but for democracy. In her view, the humanities represent a number of qualities that are unparalleled by any of the other sciences. These qualities are the following. First, they have the potential to educate students and help them become academic citizens of the world, who take societal responsibility on the basis of a thorough, emotionally grounded morality that is inclusive and diverse, as Nussbaum also, and more extensively, argues in her Political Emotions (2013). Second, the humanities can build this responsible academic citizenship through a Socratic pedagogy that values substantive arguments and imagination, which are not primarily driven by an economics-based view of the world. If we look at Stoner from this perspective, we see him almost desperately searching to 'infect' his students with the passion for academic knowledge that 'science' has awakened in himself, but which is systematically swept aside in an institutional setting that seems to be dominated by issues of power and interest, as well as disinterest for the kind of intrinsic quality that remains defenceless in a hostile - university - environment. To substantiate this argument, I include a personal story of such an environment, which, somewhat ironically, speaks of quality abundantly: the university examination committee.

Although the Stoner novel contains many more themes than academic passion, it is the love for knowledge losing out to mediocrity, self-interest, and institutional politics that stands out for me. Although my own academic environment in a Dutch medium-sized university also suffers from the above ills, I prefer telling a story - somewhere between realist, impressionist, and confessional (Van Maanen, 2011) - that revolves around excellence and quality. Universities world-wide compete in the various rankings; on their websites they usually quote the one in which their position is best. Much as what 
business corporations proclaim in their mission statements, universities refer to 'high-standard' education and 'world-class' research by 'excellent' scholars for whom quality and customer satisfaction go hand-in-hand in the production of knowledge and teaching performance. It is a common strategy to use a similar corporate language to sell the academic product on the market to as many clients as possible for the best price. Looking at the self-presentation of universities, the terminology unashamedly suggests we live in the age of the mass knowledge economy.

Quality has always been a prominent concept in the academic world. Periodically universities have to demonstrate their quality in quality assurance assessments by peers. Both research and teaching receive their share of what is considered a recurrent threat, upsetting university departments every five or six years. Until fairly recently, say 2000 , the committees doing the hearings consisted of benevolent peers who assessed most research and teaching programmes accordingly, without asking for 'measurable indicators. However, in research, output, and citation, numbers nowadays figure prominently next to impact factors and acquired research subsidies. Teaching quality is measured by the presence and interlinkage of programme goals, assessment plans, learning objectives, peer-reviewed tests, exam analyses, and overall pass rates. The Dutch Ministry of Education has made local examination committees responsible for guaranteeing the required quality standards that are formally evaluated by the Netherlands Flemish Accreditation Organisation (NVAO).

As a member of the examination committee of my faculty, I have had the doubtful pleasure to be responsible for making teaching managers and teachers accountable by making them comply to a set of quality rules, that is, by providing them with the tools and parameters to provide the examination committee with sufficient hard data to demonstrate the required quality. University-wide, this has resulted, in the production of impenetrably densely written documents and overly complete forms that, not just seldom, lead to superficial box-ticking and numb reproduction of standard formulations by teaching staff, as well as to the production of abundant numbers of quality reports by admin staff. While this quality quest (or race) is experienced as massively burdensome by practically all who are involved in it - except perhaps the growing army of official quality keepers at all university levels - the story becomes outright tragic when we take a closer look at how this predicament impacts on students and their behaviour.

Students become increasingly focused on the exact content and requirements for them to pass their exams: number of pages to be read, assessment forms, mock exams, pass rate percentages, etc. Of course, there generally is still some intellectual interaction during teaching hours, but consuming behaviour 
becomes almost standard, particularly at undergraduate level. It is not exceptional any more that the examination committee spends complete sessions with teachers going through exam questions after complaints by students. The student's course evaluations increasingly tend to be critical of the testing: often tests do not live up to what the students had expected or, in market terminology, the product is not what they had 'ordered'. They become calculating consumers who want value for money, and teachers regularly accommodate these expectations and produce the goods ordered. This quality Catch-22 produces teachers desperately asking themselves what they can still ask from their students, while the latter enter a similarly desperate search to satisfy their teachers. Those teachers who do not comply are often faced with complaints, which the examination committee confronts them with. In this way, academic consumption and production take on the traits of a calculating game in which measuring numbers suggests the triumph of (pseudo) objectivity in which academics experience serious feelings of loss. The academy - and particularly its teaching - no longer feels like home, a place to feel in one's element. The irony is that, with all their regulating zeal, examination committees, as the quality gatekeepers, contribute to this very displacement and consequently even provoke academic sloppiness.

My involvement in this quality imbroglio at times produces strong feelings of muddling through and despondency. I think it can be said that the presentday consuming university (Bauman \& Donskis, 2013; Donskis in this volume) with its quantitative and calculated understanding of quality is in danger of creating Stoner clones in larger numbers than we think. The town-and-gown dynamic described in this semi-confessional tale - like in the Hiden and Galbraith novels for that matter - leads universities to become instruments of a knowledge economy that turns an increasing segment of their academics into homeless and alienated people displaying the kind of behaviour that much resembles the desperate comportment that made reading Stoner so toe-curling.

\section{4 \\ Further Discussion: a Plea for the Public Academic}

When our academic 'home' is lost in a world where 'nothing is personal, and everything business', we seem to have gradually entered the realm of Liquid Modernity's new Satan (Kattago, 2014, p. 151). Since it will force us to decline responsibility and remove the closeness between us and the Other, we enter a state of what Bauman \& Donskis $(2013$; 2016) call adiaphora, moral blindness or numbness. As André Schwarz-Bart in his The Last of the Just dramatically argues, the latter must be resisted at all costs, even if there are only a few 
people left to do so. ${ }^{3}$ Williams' Stoner is indeed the story of a single individual resisting and refusing to succumb to fatalism, cynicism, and reneging on quality in favour of fostering quality-based empathy and belonging instead (see also De Waal, 2008). We might translate this as an urgent call to create small but steadfast Gideon's tribes, consisting of Stoner-like figures, though hopefully a bit less helpless. More concretely we need to redefine and recreate our universities as 'homes' as I already suggested in the opening of this text. As environments for and communities of critical knowledge-seekers and science-lovers, universities must emanate and embody the kind of quality around academic principles, standards, and commitment that Pirsig advocates. If academics who swim against the tide-of-the-day, yet in the tide of tradition, form such 'islands of hope' or 'safe spaces', this may be to the benefit of democratic society, which in the now often proclaimed post-truth world is more needed than ever. The fruit of academic freedom in such environment bears the responsibility to work towards the development of academic citizenship. The university where I work bears in its name the word 'free'. Its tradition may not have always fostered academic freedom, but, when it is given new substance through the academic citizenship concept, its academics might well be seduced into taking on responsibility rather than just demonstrating accountability.

Some more words about this culture of accountability or about the socalled audit culture (Strathern, 200o; referred to in a public lecture by Michael Herzfeld, The Devil in the Auditing, 12 May 2015, Leiden). Auditors - including less than a few complicit academics, as I demonstrated in my autoethnographic piece - have taken over in terms of the definition of the future of universities, a future they define as being paved with numbers. Since in such a situation we are first and foremost consumers and only then, perhaps, citizens (Kattago, 2014, p. 4), Herzfeld urges us to fight this devil of neoliberalism - which in his view is neither neo nor liberal - that has taken over academia. I think I can join him there, but the question is how best to organise the fight.

Although I believe some auditing can be good for academics and academia, we should indeed reflect on how to 'wage this war'. Our preferred strategy as tenured staff could well be the Robin Hood approach, in which we form our own small bands of Stoners and 'fight' the system wherever it manifests itself by surprise and with playful acts of defiance. Whether such a 'guerrilla' can be won is an open question, but some battling might make us happier, perhaps more effective, and will certainly secure that we end professionally less

3 The title seems to refer to the Evangelist Matthew, whose 'For where two or three are gathered together in my name, there am I in the midst of them' (18:20) urges for an equally principled stance. 
in despair than Stoner. We need spaces where we can indeed feel 'at home', so that we can play with our thoughts, share these with our students, and responsibly defend the value of this play by sharing it broadly - beyond the outlets that our auditors would like us to use.

As we have seen, academia has inspired writers to produce a number of literary novels, but they seldom present the places academics inhabit as really welcoming, 'homey' spaces. Other university novels than the ones I quoted hardly give a more favourable picture. Charlottes Brontë's The Professor (1994 [1856]) scarcely even pays any attention to the main character's profession. In John Coetzee's Disgrace (2000) literary professorship is even directly linked with moral weakness and professional boredom (though, admittedly, the novel doesn't really pretend to speak about universities). Rex Warner's the Professor (1938) provides a depressing description of the tragic fate of an academic professor accepting political responsibility. David Lodge's trilogy Changing Places (1975), Small World (1984) and Nice Work (1988) foreshadows the ever more reduced space academics experience for their calling. As noted above, John Hiden's Town and Gown depicts the nasty effects of sloppy scientists making common cause with local entrepreneurs, quite similar to the process John Kenneth Galbraith describes in his A Tenured Professor (1980), where Marvin Montgomery both tries to beat the university's tenure track system and use it for (his own) economic profit by making his scientific knowledge and skills subservient to this purpose. The university Williams depicts effectively dismantles any passion of 'true' and dedicated academics. Stoner's environment represents the type of soulless civilisation so gruesomely portrayed in Aldous Huxley's Brave New World (1932), is entirely devoid of the quality and values Pirsig's hero Phaedrus pursues in Zen and the Art of Motorcycle Maintenance (1979). If we group these literary representations - and there are definitively more - together the image arises of academia as a bound, even chained, sector that uncritically follows that latest fads and dictates from the hand that feeds it (Birnbaum, 200o), in a desperate attempt to survive at the cost of academic freedom (Higgins, 2013) and the loss of its critical voice in society.

What I have tried to argue in this piece is that universities should grant more space to the development of critical and informed knowledge and understanding - and particularly fight for the humanities as a valuable and unquestioned space in the university that is now increasingly squeezed out of the market-driven university. We need communities of learners (consisting of staff as well as students) that try to understand (Verstehen), and write about, how humans make sense (and nonsense) of the world they live in. In this endeavour some of us might want to follow Noam Chomsky's example of the public intellectual (the professor), whereas others prefer a less pro-fessing role and stay 
within the precincts of the university walls to teach, read, and write like Stoner, meanwhile educating young students in the love of knowledge and critical reflection. The latter rather live up to Ortega y Gasset's (1992 [1930]) now somewhat controversial view that doing science is indeed for the happy few, but that the university first and foremost is a place where students are being taught and learning takes place. This teaching (and learning) in Ortega's view takes place in what he calls the faculty of culture (broadly understood as multidisciplinary) that is to enlighten and provide broad (cultural) understanding of the world. If I understand him correctly this is in the end a plea for the broader liberal arts colleges that have recently become popular next to and opposed to the fast-growing mass-consumption universities. Although there is surely some elitist inclination in these colleges, they do represent the ideal that broad intellectual formation requires a serious study effort.

The humanities' emphasis on understanding and deconstructing - which has lost credibility under neoliberalism where the law of supply and demand has replaced the questions-answers pair - must regain its position of showing the way (methodos) in how we can acquire this knowledge: by asking questions, diving backstage and below the surface of first appearances and basic skills. Unlike Ortega y Gasset - who believed that doing science was eventually not for the majority of students - I think we owe our students more than half-hearted versions of science, research, and knowledge. Our present teaching and, consequently, learning are less and less the trial and error exercise of systematic doubt (in the broadest sense) but rather the testing of 'to be re-produced knowledge'. Hence teaching is increasingly considered a 'load' for university staff, standing in the way of serious research. Consequently, the attenuated current practice of teaching and research threatens the transgenerational continuity of both. As I noted in the beginning of this text, this transgenerational breach has become conspicuously visible in South Africa's present higher education sector, which is both wrestling with the spectre of its apartheid-framed institutional cultures (Jansen, 2009; Higgins, 2013; Steyn, 2001; Keet, 2015; Nkomo, 1992; Maré, 2015) and a transgressive, economistic, ominously called 'mode 2 ' (per)version of scientific knowledge (co-)production (Gibbons, 1994; see also Boutellier, 2015). The present call for scientific 'decolonisation' (cf. Mbembe, 2015) attempts to cover both misrepresentations of the knowledge-driven public mission of academia and its academics world-wide. Public intellectuals driven by this mission are now slowly standing up to adopt this post-colonial refusal to accept the simple and standard white middle-class male view of society and the market-driven instrumental rationale that mainstream science has adopted. It is time to embrace the goals of this movement and reinvigorate viable and robust humanities that provide 
safe spaces for the critical public academic practice as represented by Noam Chomsky, whose recently renewed 1977 message is now phrased Because We Say So (2015).

I would like to end with a final reflection taken from two Dutch writers. Philosopher Joke Hermsen in her Melancholie van de Onrust (2017, translation: Melancholy of Unrest) proposes a productive usage of the melancholic condition that so frequently affects us human beings these days. Melancholy can become productive when we allow room for it to develop without the pressure of chronological time. Extrapolating this idea to the field of education, she reminds us that the Greek scholè (our 'school') refers to rest, waiting, and idleness (p. 139). In present times, these meanings are not really considered to have positive connotations, but Meindert Flikkema's Sense of Serving. Reconsidering the Role of Universities Now (2016) shows that an academy that values the sense of synchronicity, place, heritage, and belonging may well enable the community of learners (or, why not, scholarly guilds, where learning through cooperation is valued, cf. Sennett 2012) to 'improve the human condition', for 'qui docet discit: he who teaches learns' (Flikkema, 2016, pp. 180-181). The scholar-educator, as craftsperson in the sense described by Sennett, is committed to this goal and accepts what Gert Biesta (2016) calls the beautiful risk of education' - which essentially is a plea to skip the pressing structures of the teaching factory, to reduce the speed that the 'academic throughput' requires (Berg \& Seeber, 2016; see also Wels in this volume), and instead to accept that students learn in unexpected and unanticipated ways. As Stoner would have it.

\section{References}

Bauman, Z., \& Donskis, L. (2013). Moral Blindness: The Loss of Sensitivity in Liquid Modernity. Cambridge, Polity Press.

Bauman, Z., \& Donskis, L. (2016). Liquid Evil. Cambridge, Polity Press.

Berg, M., \& Seeber, B.K. (2016). The Slow Professor. Challenging the Culture of Speed in the Academy. Toronto, University of Toronto Press.

Biesta, G. (2016). The Beautiful Risk of Education. Abingdon, Taylor \& Francis Ltd.

Birnbaum, R. (1988). How Colleges Work: The Cybernetics of Academic Organization and Leadership. San Francisco, Jossey-Bass.

Birnbaum, R. (2000). Management Fads in Higher Education. San Francisco, Jossey-Bass. Booysen, S. (2016). Fees Must Fall. Student Revolt, Decolonization and Governance in South Africa. Johannesburg, Wits University Press.

Boutellier, H. (2015). Het Seculiere Experiment. Hoe We van God Los Gingen Samenleven. Amsterdam, Boom. 
Brontë, C. (1994 [1856]). The Professor. Wordswore Editions.

Chomsky, N. (1977). Intellectuals and the State, Huizinga Lecture, Baarn, Het Wereldvenster.

Chomsky, N. (2014). The death of American universities. Jacobin: A Magazine of Culture and Polemic. Retrieved from: https:/www.jacobinmag.com/2014/03/the-deathof-american-universities/.

Chomsky, N. (2015). Because We Say So. London, Penguin.

Coetzee, J.M. (2000). Disgrace. New York, Vintage.

De Waal, F. (2008). Putting the altruism back into altruism: The evolution of empathy. Annual Review of Psychology , 59, 279-300.

Flikkema, M. (ed.) (2016). Sense of Serving. Reconsidering the Role of Universities Now. Amsterdam, VU University Press.

Galbraith, J.K. (1990). A Tenured Professor. London, Houghton Mifflin Company.

Gibbons, M. (ed.). (1994). The New Production of Knowledge: The Dynamics of Science and Research in Contemporary Societies. London, Sage.

Hermsen, J.J. (2017). Melancholie van de Onrust. Rotterdam, Lemniscaat.

Herzfeld, M. (2015). The Devil Is in the Auditing. Public lecture University of Leiden, 12 May 2015.

Hidden, J. (2012). Town and Gown. Stoney Stanton, Indigo Dreams Publishing.

Higgins, J. (2013). Academic Freedom in a Democratic South Africa. Essays and Interviews on Higher Education and the Humanities. Johannesburg, Wits University Press.

Huxley, A. (1932). Brave New World. London, Chatto \& Windus.

Ignatieff, M. (2013). Civil Courage and The Moral Imagination. Retrieved from https:// openaccess.leidenuniv.nl/bitstream/handle/1887/51368/Cleveringarede2o13boekje .pdf? sequence=1.

Jansen, J. (2009). Knowledge in the Blood. Confronting Race and the Apartheid Past. Stanford, Stanford University Press.

Jansen, J. (2017). As by Fire. The End of the South African University. Cape Town, Tafelberg.

Kattago, S. (2014). In the shadow of Antigone: Resisting moral blindness. Journal of Political Power, 7 (1), 149-154.

Keet, A. (2015). Institutional Cultures/Environment. Briefing paper prepared for the second national Higher Education Transformation Summit, 2015. Retrieved from http:// www.justice.gov.za/commissions/FeesHET/docs/2015-HESummit-Annexure1o.pdf.

Lodge, David (1975). Changing Places: A Tale of Two Campuses. London, Secker and Warburg.

Lodge, David (1984). Small World: An Academic Romance. London, Secker and Warburg. Lodge, David (1988). Nice Work. London, Secker and Warburg.

Maré, G. (2015). Declassified. Moving Beyond the Dead End of Race in South Africa. Auckland Park, Johannesburg: Jacana.

Margetts, H., \& Hood, C. (2010). Paradoxes of Modernization: Unintended Consequences of Public Policy Reform. Oxford: Oxford University Press. 
Mbembe A. (2015). Decolonizing Knowledge and the Question of the Archive. Retrieved from http://www.staugustine.ac.za/sites/default/files/ctools/13.\%2oMbembe\%2o -\%2oDecolonizing\%2oKnowledge...\%20\%282015\%29.pdf.

Nietzsche, F. (2008 [1882]). The Gay Science. Cambridge, Cambridge University Press.

Nkomo, S. (1992). The emperor has no clothes: Rewriting 'Race in Organizations'. The Academy of Management Review, 17 (93), 487-513.

Noordegraaf, M., \& Schinkel, W. (2011). Professional capital contested: A bourdieusian analysis of conflicts between professionals and managers. Comparative Sociology, $10(1), 97-125$.

Nussbaum, M.C. (2010). Not for Profit. Why Democracy Needs the Humanities. Princeton, Princeton, NJ, Princeton University Press.

Nussbaum, M.C. (2013). Political Emotions. Why Love Matters for Justice. Cambridge MA, Harvard University Press.

Ortega y Gasset, J. (1992 [1930]). Mission of the University. (La Misión de la Universidad, Buenos Aires). London, Transaction Publishers.

Paradeise, C., \& Thoenig, J.C. (2013). Academic institutions in search of quality: local orders and global standards. Organisation Studies, 34 (2), 189-218.

Pirsig, R.M. (1979[1974]). Zen and the Art of Motorcycle Maintenance. An Inquiry into Values. New York: Quill.

Ray, M. (2016). Free Fall. Why South African Universities Are in a Race against Time. Johannesberg, Bookstorm.

Sennett, R. (2008). The Craftsman. London, Penguin.

Sennett, R. (2012). Together. The Rituals, Pleasures \& Politics of Cooperation. London, Penguin.

Steyn, M. (2001). Whiteness Isn't What it Used to Be. White Identity in a Changing South Africa. New York, SUNY Press.

Strathern, S. (2000). Audit Cultures: Anthropological Studies in Accountability, Ethics, and the Academy. New York, London: Routledge.

Tabensky, P., \& Matthews, S. (2015). Being at Home. Race, Institutional Culture and Transformation at South African Higher Education Institutions. Pietermaritzburg, UKZN Press.

Van Maanen, J. (2011 [1988]) Tales of the Field: On Writing Ethnography. Chicago, Chicago University Press.

Vice, S. (2010). How do I live in this strange place? Journal of Social Philosophy, 41, $323-342$.

Warner, R. (1938). The Professor. London, John Lane.

Weber, M. (1946 [1919]). Science as a vocation. In From Max Weber: Essays in Sociology, New York: Oxford University Press, 129-156.

Williams, J. (2006 [1965]). Stoner. New York Review Books Classics. 